\title{
STATISTICAL ANALYSIS OF DIESEL ENGINE PERFORMANCE FOR CASTOR AND JATROPHA BIODIESEL-BLENDED FUEL
}

\author{
Devendra Vashist ${ }^{1, *}$ and Mukhtar Ahmad ${ }^{2}$ \\ ${ }^{1}$ Department of Automobile Engineering, Manav Rachna International \\ University, Faridabad, Haryana, India. \\ *E-mail: vashist_dev2001@yahoo.co.in \\ ${ }^{2}$ Department of Mechanical Engineering, Faculty of Engineering and Technology \\ Jamia Millia IslamiaNew Delhi, India.
}

\begin{abstract}
Vegetable oils and their methyl/ethyl esters are alternative renewable fuels for compression ignition engines. Asian countries are not self-sufficient in edible oil and are exploring non-edible seed oils, like jatropha and castor as biodiesel raw materials. In the present study jatropha and castor oil were used for the preparation of biodiesel by the transesterification process. Diesel and jatropha oil methyl ester (JOME) blends were used to conduct short-term engine performance tests at varying loads. Similar tests were conducted with castor oil methyl ester (COME). The engine parameters were recorded and compared for the prepared blends. The best engine operating condition based on lower brake specific fuel consumption and higher brake thermal efficiency were identified and compared. The maximum thermal efficiency was observed at $13 \%$ substitution of COME in diesel and 18\% for JOME in diesel. An analysis of variance test was applied to the observed data for both the fuels. Results indicated for COME, F $=2.397$, that there is no significant effect on fuel consumption with the fuel type. There is a significant effect on fuel consumption and thermal efficiency with $\%$ of load. For $\mathrm{F}$ $=5.69$ there is a significant effect on thermal efficiency with the fuel type. Similar trends were observed with JOME blends. These trends indicated that blends in the ratio of $0-20 \%$ by volume of biodiesel can be added to neat diesel without any change in the hardware of the engine.
\end{abstract}

Keywords: Transesterification; Jatropha oil methyl ester; Castor oil methyl ester; Brake thermal efficiency; Engine exhaust temperature; Fuel consumption; F test.

\section{INTRODUCTION}

Rudolf Diesel, the inventor of the diesel engine, presented the concept of using biofuels in diesel engine sat the 1911 World's Fair in Paris. R\&D activities in this area were not carried out because of the abundant supply of petro-diesel at that time. Only recently was the importance of biofuels realised when it was noticed that petro-diesel resources are depleting fast and additionally that they are polluting the environment [1]. Recently many serious efforts have been made by several researchers to use different sources of energy as fuel in existing diesel engines. The higher viscosity of neat vegetable oil makes it an incompetent fuel for direct use in a diesel engine. The injectors of the engines get choked after a few hours if they are directly run on neat vegetable oil [2]. The viscosity of neat oils can be reduced by blending them with diesel or by the process of transesterification, which produces biodiesel. Worldwide transesterification has been 
accepted as an effective means of biodiesel production and viscosity reduction of vegetable oil. The transesterification process is influenced by temperatures, catalyst type, the concentration ratio of alcohol to fuel and stirring speed rate [3]. The important compositional difference between biodiesel and diesel fuel is concerned with oxygen content. Biodiesel contains 10-12\% oxygen in weight basis and this lowers the energy content. The lower energy content causes reductions in engine torque and power [2, 47]. It has been reported that biodiesel containing oxygen reduces exhaust emissions such as $\mathrm{HC}$ and $\mathrm{CO}$ mainly because of complete combustion. Since biodiesel contains little sulphur compared to diesel fuel, a significant reduction in $\mathrm{SO}_{2}$ emission was observed by Usta [8].

The price of edible vegetable oils is higher than that of diesel fuel. Therefore, instead of using such oils, waste vegetable oils $[9,10]$ and non-edible crude vegetable oils $[11,12]$ have been considered as potential alternative fuels. Different researchers are working on different types of oil to be used as a potential source for biodiesel production, such as jatropha oil [11, 13], castor oil [14], polanga seed oil [4], karanja oil [15], palm oil [16, 17], tobacco oil [8], coffee oil [18], mahua oil [19], rubber seed oil [20], microalgae oil [21], rice bran oil [22], beef tallow [23], waste cooking oil [9], linseed oil [1], soyabeen oil [24], and sunflower oil [25]. To compensate for the shortages of diesel fuel, the adaptation of a selected alternative fuel to suit the diesel engine is considered more economically attractive in the short-term than engine modification to suit the fuel. For this purpose, an alternative liquid fuel that will blend readily with diesel fuel is required. Such an alternative fuel should lend itself to local production in adequate and economic quantities. There should be few modifications to the existing engine. Engine performance and durability should not be affected significantly. In the present investigation, two non-edible oils are taken, i.e. castor seed oil and jatropha seed oil. Biodiesel from both the oils were produced and then studied in a compression ignition engine. A comparison was made between the two sources of oil production and a comparative analysis was made on their usage in the internal combustion engine. Which type of seed will be suitable for a particular region and how blends of both the oils differ from each other when used in existing engines is the basic motivation behind the research in this paper.

\section{JATROPHA CURCAS}

Jatropha curcas is a plant belonging to the Euphorbiaceae family that produces a significant amount of oil from its seeds. This is a non-edible oil-bearing plant widespread in arid, semi-arid, and tropical regions of the world. Jatropha is a droughtresistant perennial tree that grows in marginal lands and can live for over 50 years [26]. The oil content in jatropha seed is reported to be in the range of 30 to $50 \%$ by weight of the seed and ranges from 45 to $60 \%$ by weight of the kernel itself [26]. The jatropha tree has several beneficial properties: its stem can be used as a natural tooth paste and brush; latex from the stem can be used as a natural pesticide and for wound healing; and its leaf can be used as feed for silkworms, among other uses. It is a fast-growing tree and easily propagated. Jatropha usually grows below $1400 \mathrm{~m}$ above sea level and requires a minimum rainfall of $250 \mathrm{~mm}$, with an optimum rainfall of 900-1200 $\mathrm{mm}$ [2]. This plant is not even browsed by animals for its leaves. Figure 1 shows jatropha seed, fruit and plant at the Manav Rachna International University campus. 

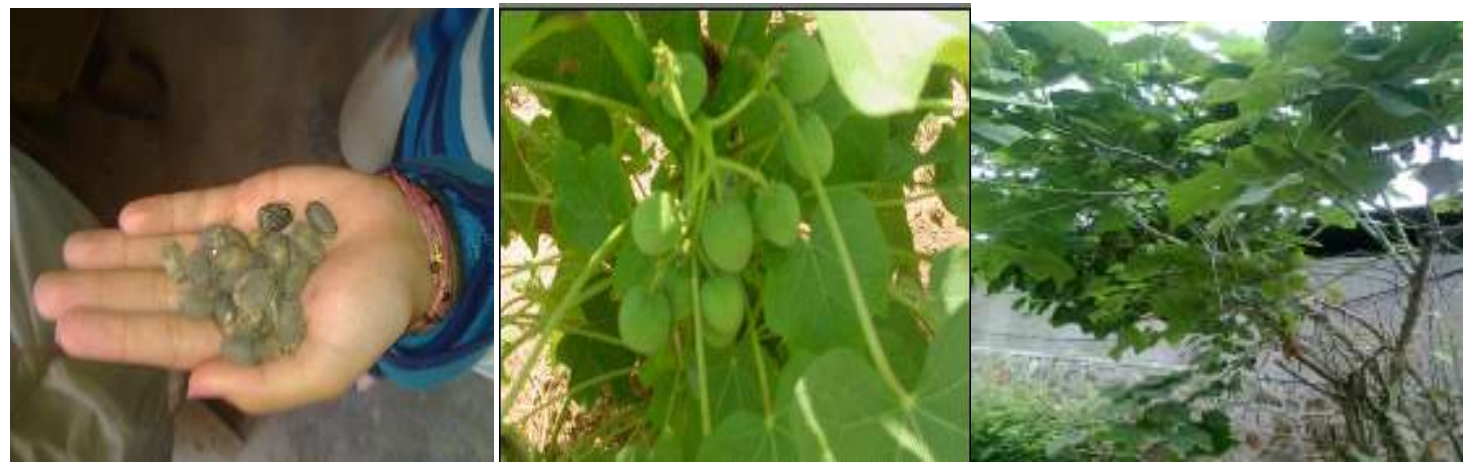

Figure 1. Jatropha seed, fruit and plant.

\section{CASTOR PLANT (RICINUS COMMUNIS)}

The castor oil plant, Ricinuscommunis, is a species of flowering plant in the spurge family, Euphorbiaceae. Castor is indigenous to the south-eastern Mediterranean Basin, Eastern Africa, and India. Castor seed is the source of castor oil, which has a wide variety of uses. The seeds contain between 40 and $60 \%$ oil that is rich in triglycerides, mainly ricinolein. The seed contains ricin, a toxin, which is also present in lower concentrations throughout the plant. It is a fast-growing, suckering perennial shrub which can reach the size of a small tree (around $12 \mathrm{~m} / 39 \mathrm{ft}$ ). Figure 2 shows the castor plant and pod at the university campus.

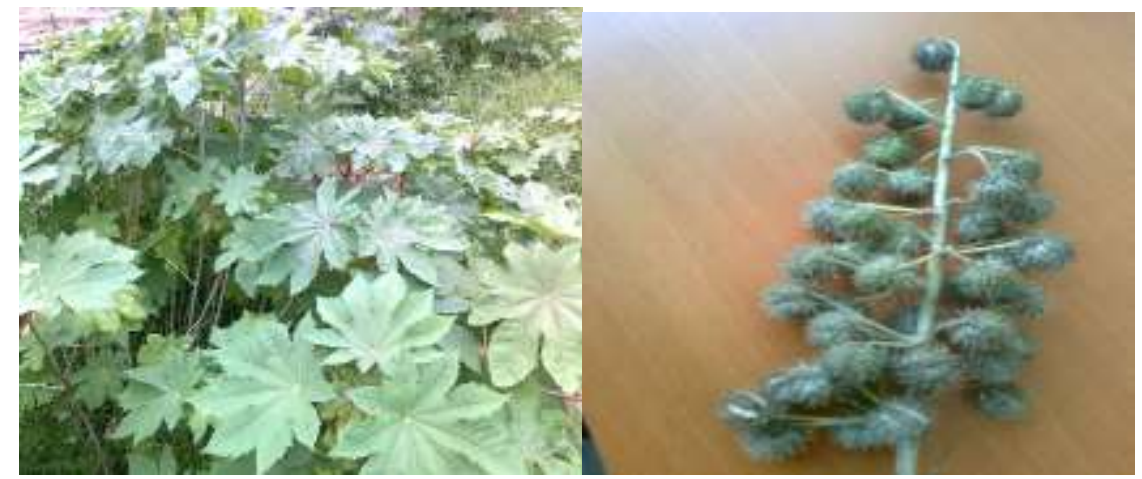

Figure 2. Castor plant and Pod.

The glossy leaves are 15-45 cm long, long-stalked, alternate and palmate with 512 deep lobes with coarsely toothed segments. The fruit is a spiny, greenish (to reddish purple) capsule containing large, oval, shiny, bean-like, highly poisonous seeds with variable brownish mottling. In areas with a suitable climate, castor establishes itself easily as an apparently "native" plant and can often be found on wasteland. If sown early, under glass, and kept at a temperature of around $20{ }^{\circ} \mathrm{C}$ until planted out, the castor oil plant can reach a height of $2-3 \mathrm{~m}$ in a year. The toxicity of raw castor beans is due to the presence of ricin, a poisonous substance. The toxin provides the castor oil plant with some degree of natural protection from insect pests, such as aphids. In fact, ricin has been investigated for its potential use as an insecticide. The castor oil plant is also the source for undecylenic acid, a natural fungicide. Global castor seed production is around 1 million tons per year. Leading producing areas are India (with over $60 \%$ of 
the global yield), China and Brazil, and it is widely grown as a crop in Ethiopia. Table 1 shows the top ten producers of castor oil.

Table 1. Top ten castor oil seed producers.

\begin{tabular}{lc}
\hline \multicolumn{1}{c}{ Country } & Production (Tonnes) \\
\hline India & 830000 \\
People's Republic of China & 210000 \\
Brazil & 91510 \\
Ethiopia & 15000 \\
Paraguay & 12000 \\
Thailand & 11052 \\
Vietnam & 5000 \\
South Africa & 4900 \\
Philippines & 4500 \\
Angola & 3500 \\
World & $\mathbf{1 2 0 9 7 5 6}$ \\
\hline
\end{tabular}

\section{COMPARISON BETWEEN THE JATROPHA \& CASTOR PLANT}

A comparison of the castor and jatropha plant has been made, which is shown in the Table 2. From the table it is indicated that both the two plants require different conditions for their growth. Both of them are toxic plants and do not compete with crops for production. Both the plants are also not grazed by the animals.

\section{ESTERIFICATION OF CASTOR AND JATROPHA SEED OIL}

Castor and jatropha oil were converted into biodiesel by a two- and three-stage transesterification reaction, respectively. For castor oil the two-stage transesterification was adopted since the free fatty acid (FFA) value was less than $2 \%$ after the first stage of transesterification process, while for jatropha oil the three-stage process was adopted. One litre of both the oils was treated with $4 \mathrm{ml}$ of toluene and orthrophosphoric acid in the first stage. FFA value was then calculated: jatropha oil, which had more than a $2 \%$ FFA value, was then treated with methanol and sulphuric acid in the second stage, while in the third stage it was treated with potassium hydroxide and sulphuric acid; castor oil, which had a lower FFA (less than 2\%) value, was only treated with methanol and sulphuric acid for the completion of the transesterification process. In the second stage $75 \mathrm{ml} /$ litre of oil and $5.5 \mathrm{ml} /$ litre of oil of sulphuric acid was added to jatropha oil while in the third stage $100 \mathrm{ml} /$ litre of oil and $8 \mathrm{gm} /$ litre of oil of potassium hydroxide was added to jatropha and castor oil. A reaction temperature of $65^{\circ} \mathrm{C}, 50^{\circ} \mathrm{C} \& 65^{\circ} \mathrm{C}$ during $1 \mathrm{hr}, 3 \mathrm{hrs}$, and $3 \mathrm{hrs}$, respectively, and a stirring speed of $450 \mathrm{rpm}$ were maintained in the first, second and third stages of transesterification, respectively. Thereafter the reactant material was poured into a transparent vessel and allowed to cool at room temperature for $12 \mathrm{~h}$. It was allowed to settle for the separation of glycerol as the bottom layer. The upper layer of biodiesel was put into another transparent vessel for washing with an equal amount of water. The biodiesel was heated up to $100^{\circ} \mathrm{C}$ for $10 \mathrm{~min}$ to remove excess water. Then the biodiesel was cooled down to room temperature before use, presenting an $84 \%$ yield from jatropha oil and a $90 \%$ yield from castor oil. 
Table 2. Comparison of the castor and jatropha plant.

\begin{tabular}{|c|c|c|}
\hline Properties & Jatropha & Castor \\
\hline Land requirement & $\begin{array}{l}\text { 1. Low fertility marginal, degraded, } \\
\text { fallow waste and other lands. } \\
\text { 2. Arid and semi-arid and even on } \\
\text { alkaline soils [12]. }\end{array}$ & $\begin{array}{l}\text { 1. Alkaline or acid soils, as long } \\
\text { as the subsoil is permeable and } \\
\text { there is good drainage. } \\
\text { 2. Arid and semi-arid } \\
\text { 3. Seed will not set if soil } \\
\text { moisture is inadequate. } \\
\text { 4. Castor beans should not be } \\
\text { planted in an area that is subject } \\
\text { to erosion. }\end{array}$ \\
\hline Rainfall & $\begin{array}{l}\text { It can be grown in areas of low rainfall } \\
(200 \mathrm{~mm} / \text { year })\end{array}$ & $\begin{array}{l}\text { It requires only moderate rainfall } \\
\text { (approx. 600mm/year) and can } \\
\text { withstand long periods of } \\
\text { drought, but will thrive under } \\
\text { higher rainfall. }\end{array}$ \\
\hline $\begin{array}{l}\text { Where plantation } \\
\text { can be done }\end{array}$ & $\begin{array}{l}\text { It is ideal to replant on marginal lands } \\
\text { to prevent desertification and erosion. }\end{array}$ & $\begin{array}{l}\text { It is ideal to replant on marginal } \\
\text { lands to prevent desertification } \\
\text { and erosion. }\end{array}$ \\
\hline Effect on cattle & $\begin{array}{l}\text { It attracts no insects and is not } \\
\text { browsed by cattle or sheep. } \\
\text { Propagation by seed/cutting is easy. }\end{array}$ & $\begin{array}{l}\text { Raw castor beans are toxic due to } \\
\text { the presence of ricin and are not } \\
\text { browsed by cattle or sheep. }\end{array}$ \\
\hline $\begin{array}{l}\text { Production per } \\
\text { hectare }\end{array}$ & $\begin{array}{l}\text { Jatropha seeds ( } 0.4-12.5 \text { tons/ha/year) } \\
\text { can be easily plucked. }\end{array}$ & $\begin{array}{l}\text { Each hectare of castor oil bean } \\
\text { plants planted in arid and semi- } \\
\text { arid regions produces } 350-650 \mathrm{~kg} \\
\text { of oil. }\end{array}$ \\
\hline $\mathrm{CO}_{2}$ absorption & High carbon dioxide absorption level & $\begin{array}{l}\text { The estimated carbon dioxide } \\
\text { absorption level of castor bean } \\
\text { plants is } 34.6 \text { tonnes per hectare, } \\
\text { with two growing cycles per year. }\end{array}$ \\
\hline $\begin{array}{l}\text { Competitionwith } \\
\text { food crops }\end{array}$ & $\begin{array}{l}\text { The jatrophaplant does not compete } \\
\text { with food crops, as it can be grown on } \\
\text { marginal lands, which are not } \\
\text { competingwith food production lands. }\end{array}$ & $\begin{array}{l}\text { Castor bean does not compete } \\
\text { with food crops, as castor bean } \\
\text { can be grown on marginal lands, } \\
\text { which are not competingwith } \\
\text { food production lands. }\end{array}$ \\
\hline Temperature & $\begin{array}{l}\text { Average annual temperature well } \\
\text { above } 20^{\circ} \mathrm{C}[26] .\end{array}$ & $\begin{array}{l}\text { Castor beans grow best where } \\
\text { temperatures remain fairly high } \\
\text { throughout the growing season of } \\
140 \text { to } 180 \text { days. The seed may } \\
\text { fail to set, however, if the } \\
\text { temperature stays above } 100^{\circ} \mathrm{F} \\
\text { for an extended period. }\end{array}$ \\
\hline Oil content & $\begin{array}{l}\text { Seeds contain non-edible oil } 35 \% \text { and } \\
\text { oil yield per hectare }\end{array}$ & $\begin{array}{l}\text { The seeds contain between } 40 \% \\
\text { and } 60 \% \text { oil by weight. }\end{array}$ \\
\hline
\end{tabular}

Transesterification, which is also called alcoholysis, is a process of substitution of the radical of an ester with the radical of one alcohol. It is the same process as hydrolysis, except for the fact that alcoholis used instead of water. The transesterification reaction is represented by the general Eq. (1).

$$
\mathrm{RCOOR}{ }^{\prime}+\mathrm{R} " \mathrm{OH} \leftrightarrow \mathrm{RCOOR} "+\mathrm{R}{ }^{\prime O H}
$$


Important properties of transesterified oils were evaluated for comparison with diesel available in the local market. These are given in Table 3.

Table 3. Chemical properties of jatropha and castor oil.

\begin{tabular}{lccccc}
\hline Parameters & $\begin{array}{l}\text { Jatropha } \\
\text { oil }\end{array}$ & $\begin{array}{l}\text { Castor } \\
\text { oil }\end{array}$ & $\begin{array}{l}\text { Jatropha } \\
\text { biodiesel } \\
100 \%\end{array}$ & $\begin{array}{l}\text { Castor } \\
\text { biodiesel } \\
100 \%\end{array}$ & $\begin{array}{c}\text { High } \\
\text { speed } \\
\text { diesel }\end{array}$ \\
\hline Density at $25^{\circ} \mathrm{C}\left(\mathrm{kg} / \mathrm{m}^{3}\right)$ & 960 & 950 & 875 & 905 & 810 \\
Kinematic viscosity mm $/ \mathrm{sec}$ & 240 & 230 & 13 & 12.5 & 3.05 \\
Flash point $\left({ }^{\circ} \mathrm{C}\right)$ & 340 & 305 & 140 & 115 & 53 \\
Fire point $\left({ }^{\circ} \mathrm{C}\right)$ & 350 & 320 & 150 & 121 & 56 \\
\hline
\end{tabular}

The density of the fuel was found using mass and volume measurement apparatus, the kinematic viscosity of the oil was determined with the help of a Redwood Viscometer and the flash point was obtained from Pensky-Martens apparatus (Plate 3)as per the standard test procedure of the Bureau of Indian Standards (IS: 1448-1970). The prepared jatropha oil methyl ester and castor oil methyl ester was mixed with diesel in four different proportions, i.e. 5\%, 10\%,15\% and 20\%, to prepare its blends, i.e. JOME5, JOME10, JOME15, JOME20, COME5, COME10, COME15, and COME20. Figure 3 shows the prepared sample blends of JOME and COME.

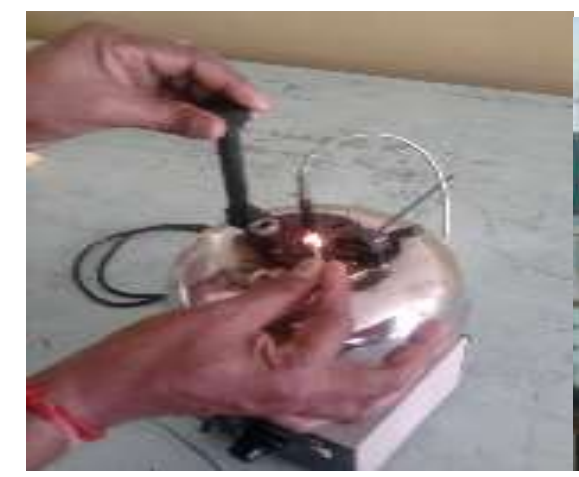

(a)

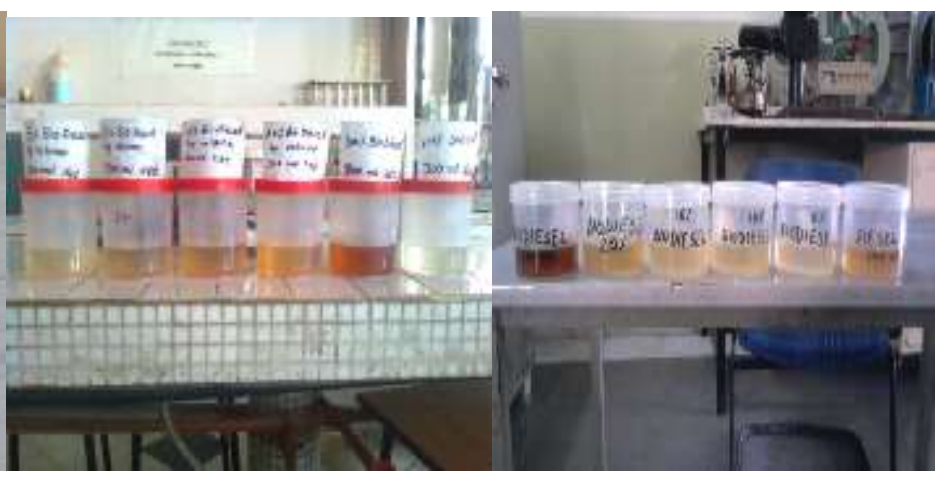

(b)

(c)

Figure 3. (a) Panksy martin flash point apparatus; (b) JOME samples; (c) COME samples.

\section{EXPERIMENTAL METHODOLOGY}

A four-stroke single-cylinder diesel engine (Figure 4) with mechanical rope brake loading was used for this study. The specifications of the engine are shown in Table 4. The inlet valve opens at $4.5^{\circ}$ before top dead centre and closes at $35.5^{\circ}$ after bottom dead centre, the exhaust valve opens $35.5^{\circ}$ before bottom dead centre and closes $4.5^{\circ}$ after top dead centre. The engine was tested with pure diesel and prepared blends of jatropha and castor biodiesel at 25\%, 50\%, 75\%, and 100\% loading at a speed of 1500 rpm only. The engine was started with standard diesel fuel and warmed up. The warm up period ends when the cooling water temperature is stabilised. Then fuel consumption, brake power, brake-specific fuel consumption, brake thermal efficiency and exhaust gas temperature were measured with different blends of jatropha and castor methyl ester. 
Table 4. Engine specification.

\begin{tabular}{ll}
\hline Description & Value and unit \\
\hline BHP & 5 \\
Speed & 1500 RPM \\
Number of cylinders & ONE \\
Compression Ratio & $16.5: 1$ \\
Bore & $80 \mathrm{~mm}$ \\
Stroke & $110 \mathrm{~mm}$ \\
Orifice Diameter & $20 \mathrm{~mm}$ \\
Type of Ignition & Compression Ignition \\
Method of loading & Rope Brake \\
Method of Starting & Crank Start \\
\hline
\end{tabular}

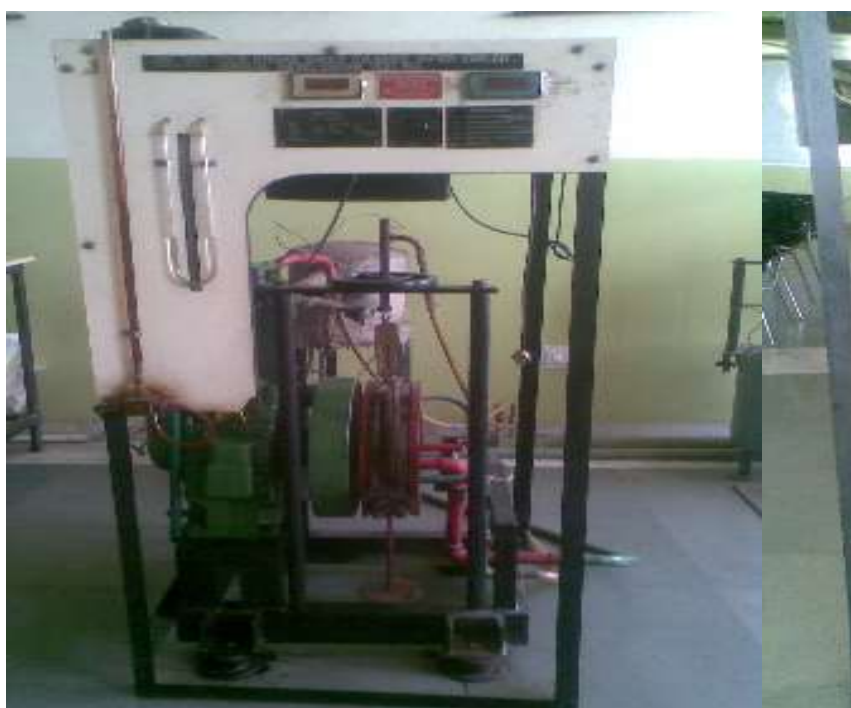

(a)

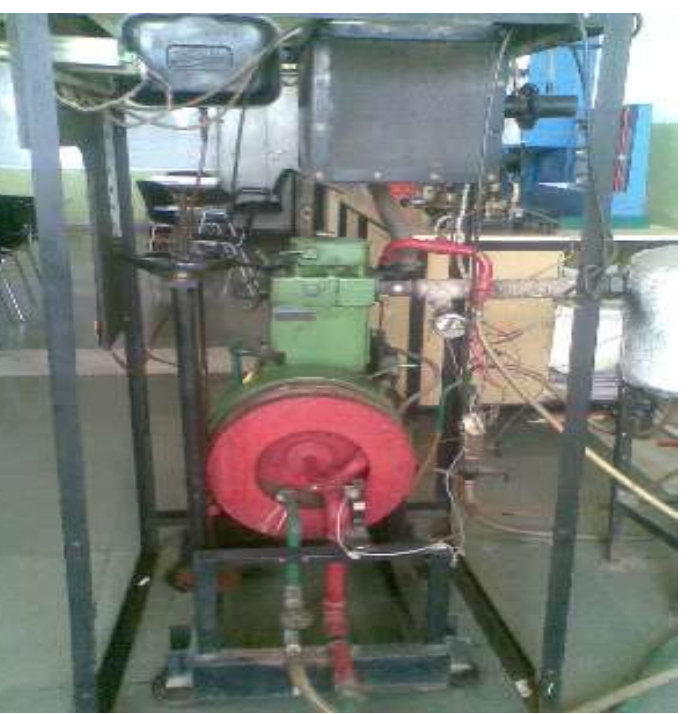

(b)

Figure 4. (a) Single cylinder diesel engine, (b) Rope brake dynamometer.

\section{RESULTS AND DISCUSSION}

\section{Effect of Loading on Brake Thermal Efficiency}

Figure 5a and5b depict brake thermal efficiency versus load for diesel COME and diesel JOME fuel blends, respectively. It was noticed that for all the fuels blends, brake thermal efficiency had the tendency to increase with an increase in the applied load. This is due to the reduction in heat loss and increase in power developed with an increase in load [2]. The figure shows a slight improvement in brake thermal efficiency with biodiesel addition up until the $13 \%$ substitution level for COME and18\% for JOME. The molecules of biodiesel contain some amount of oxygen, which takes part in the combustion process $[1,2,4,8]$. It was observed that after a certain limit with respect to biodiesel blend the thermal efficiency trend is reverted and it starts decreasing as a function of the concentration of biodiesel in the blend. This may be due to improved combustion with a lower percentage substitution of biodiesel in diesel and this effect being offset in a higher substitution due to lower calorific value [1]. The maximum thermal efficiency has been observed at $13 \%$ substitution of COME in diesel and $18 \%$ 
for JOME. The lower brake thermal efficiency obtained for COME20 \& JOME20 could be due to the reduction in calorific value and an increase in fuel consumption compared with lower concentration biodiesel diesel blends. It has been observed that brake thermal efficiency at full load for COME20isbetween 24.92 and 20.8\% for JOME20, and dieselis $23.95 \%$ and $20.8 \%$, respectively, suggesting that brake thermal efficiency for the biodiesel20 blend is comparable with diesel.

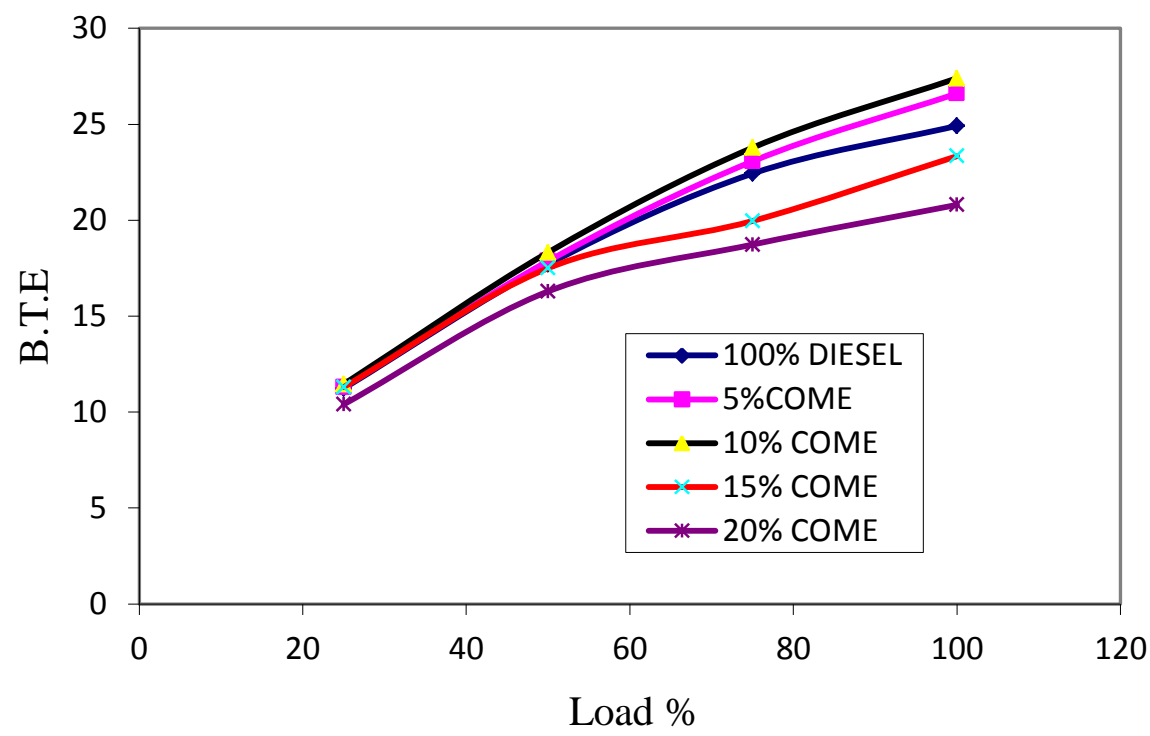

(a)

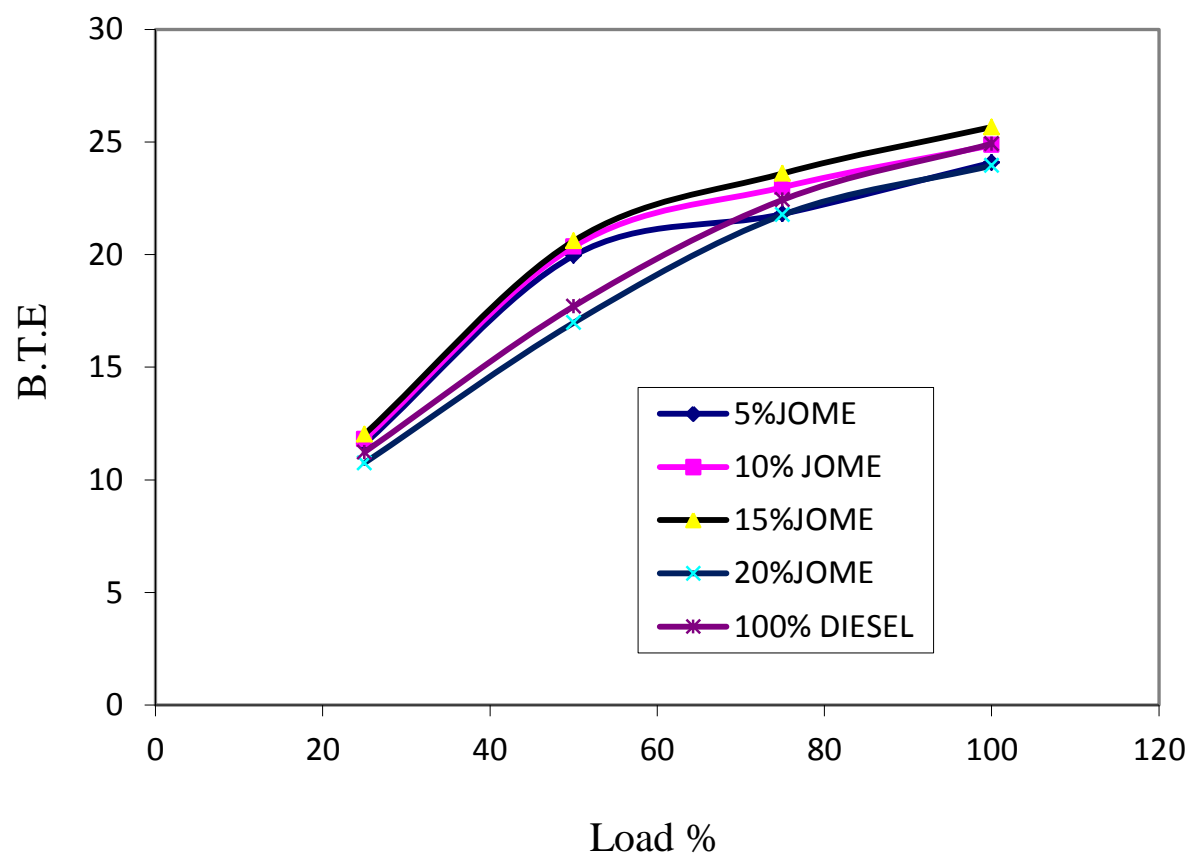

(b)

Figure 5. Brake thermal efficiency versus load for (a) COME and (b) JOME blends. 


\section{Effect of Load on Brake-specific Fuel Consumption}

Figure $6 \mathrm{a}$ and6b show the effect of load on brake-specific fuel consumption. More fuel is consumed with the increase in the load for all the blends. The optimum fuel blend is determined by taking the average of the results. It can be seen that more fuel is consumed when the percentage of biodiesel is increased beyond $13 \%$ and $18 \%$ for COME and JOME blends, respectively. This is because diesel has more calorific value compared with that of biodiesel $[1,2,4,8]$. Therefore, COME13 and JOME18 are the recommended fuel blend when all the test fuels are compared with respect to BSFC against load over the entire range of engine operations.

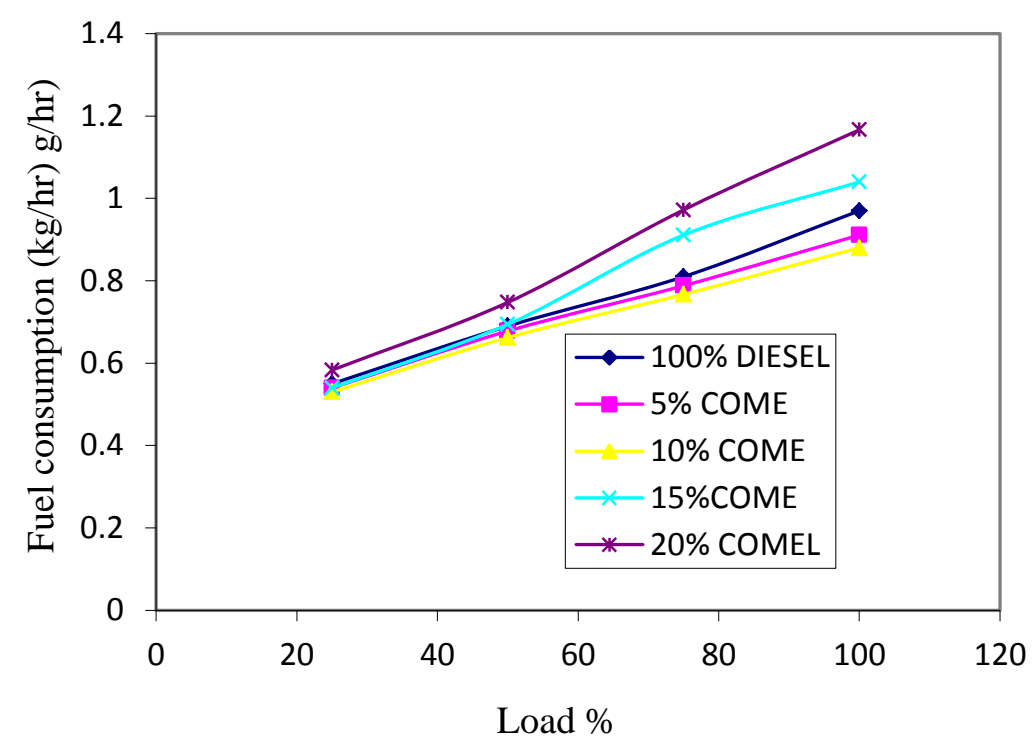

(a)

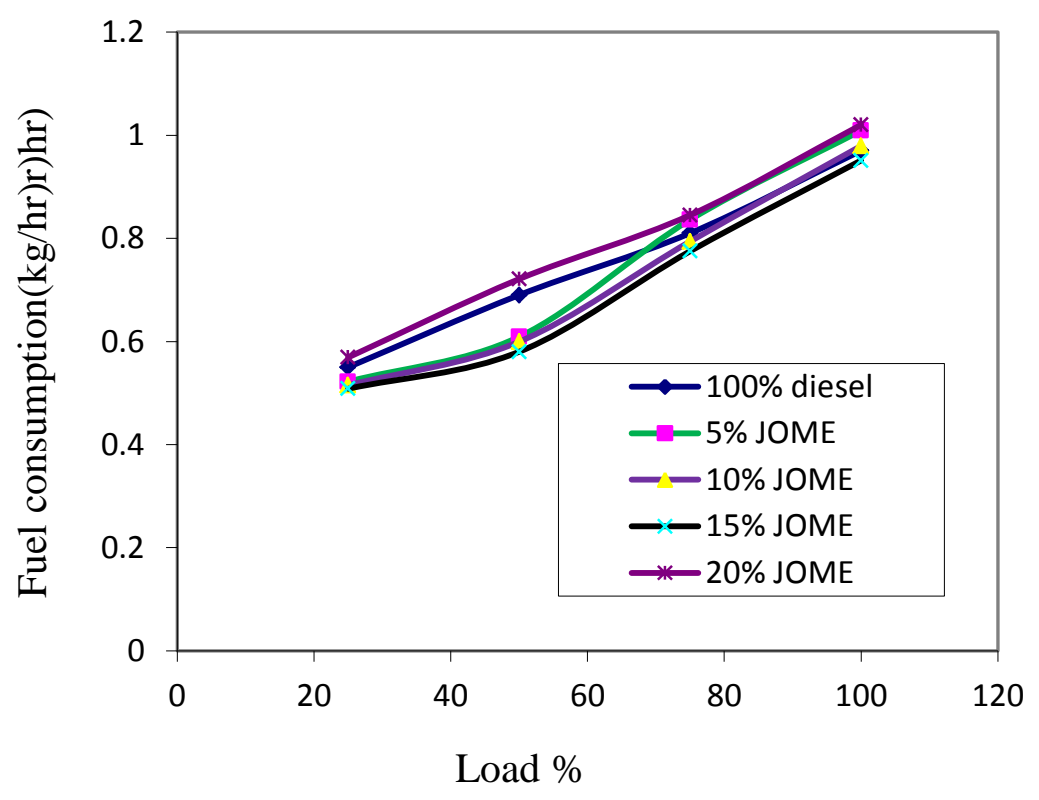

(b)

Figure 6. Fuel consumption versus load for (a) COME and (b) JOME blends. 


\section{Effect of Loading on Engine Exhaust Temperature}

The engine exhaust gas temperature measurements for castor and jatropha biodiesel blends are shown in Figure $7 \mathrm{a}$ and $7 \mathrm{~b}$. The figure shows that for mineral diesel fuel the temperature is less compared with biodiesel-blended fuel mixtures. This is basically due to the lower burning temperature which is developed in the combustion chamber when using mineral diesel as fuel. Biodiesel, which has a higher oxygen content (as well as a higher flash point) tends to burn at higher temperatures than mineral diesel fuel $[1,2,4$, 8]. In methyl esters heat release always takes place in advance compared with diesel and injection also starts earlier in the case of biodiesel as a fuel and average cylinder gas temperature was observed to be higher in the case of biodiesel as a fuel [1].

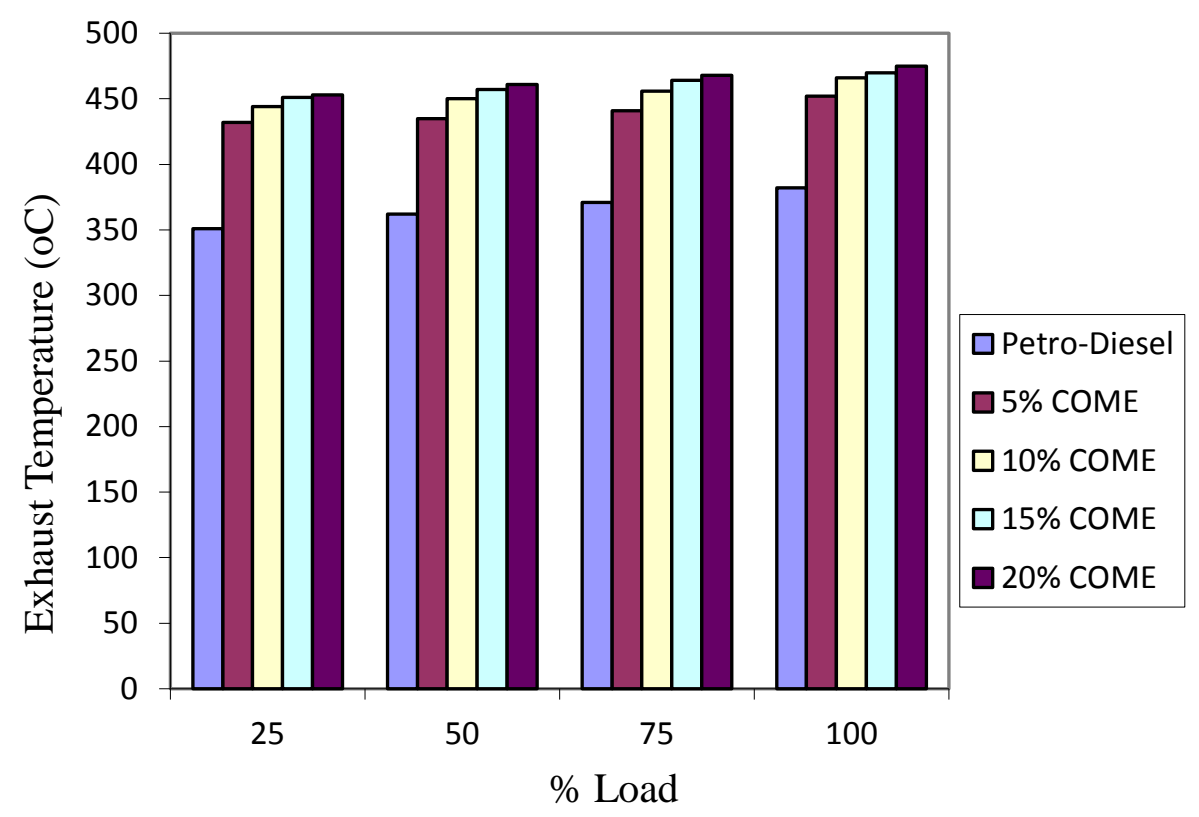

(a)

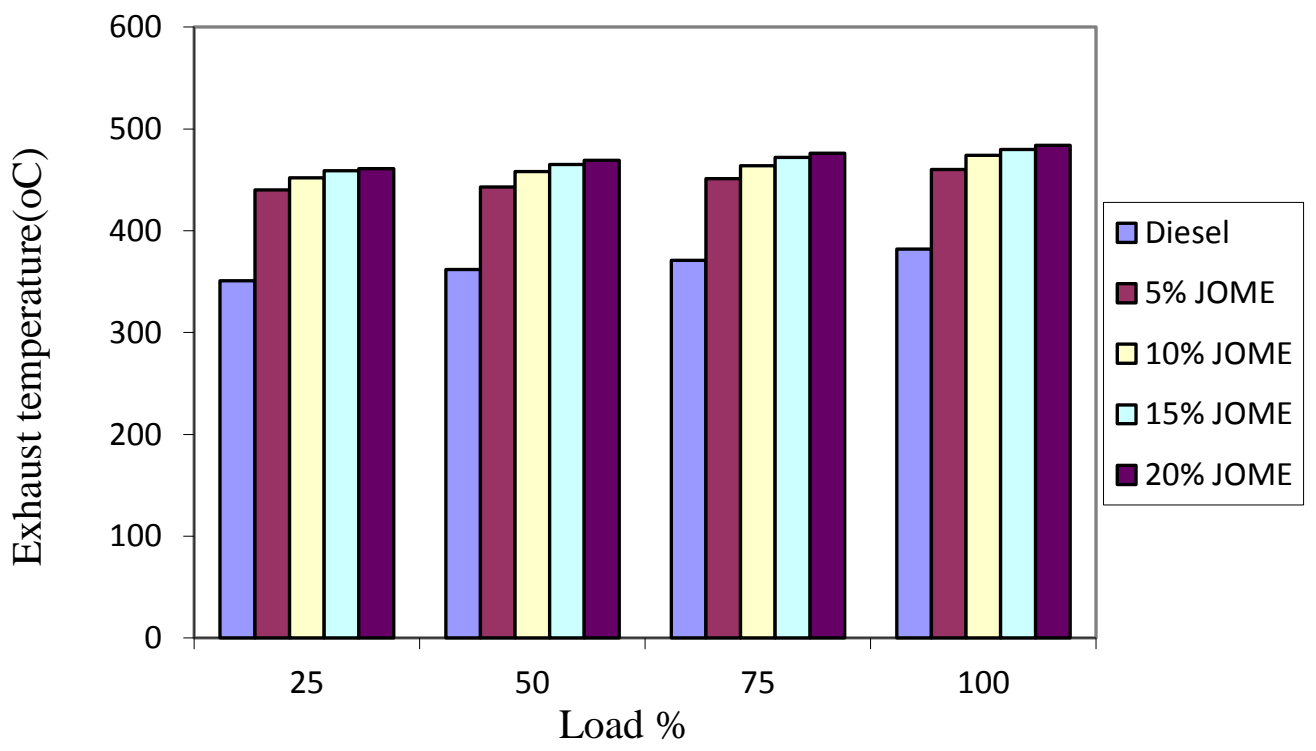

(b)

Figure 7. Engine exhaust temperature for different load using five fuel types. 


\section{TWO WAY ANOVA (ANALYSIS OF VARIANCE) OR F TEST}

\section{Statistical ANOVA Test (Fuel Consumption with \% of Load)}

Two way ANOVA tests were conducted on five fuel types for the observed data shown in Table 5.After the application of the ANOVA test, Table 6 was formed. For $v_{4,12}$, table value of $F_{0.05}=3.26$, which is more than the calculated value (2.397), the null hypothesis holds true, hence there is no significant effect on fuel consumption with the fuel type. For $v_{3,12}$, table value of $F_{0.05}=3.49$, which is less than the calculated value (25.38), the null hypothesis is rejected, hence there is a significant effect on fuel consumption with \% of load. Similarly, results were obtained for the JOME blends shown in Table 5. For $v_{4,12}$ table value of $F_{0.05},=3.26$, which is more than the calculated value (1.67), the null hypothesis holds true, hence there is no significant effect on fuel consumption with the fuel type. For $v_{3,12}$ table value of $F_{0.05},=3.49$, which is less than the calculated value (78.92), the null hypothesis is rejected, hence there is a significant effect on fuel consumption with $\%$ of load $[1,2,4,8]$.

Table 5. Observed data for COME and JOME blends.

\begin{tabular}{llllll}
\hline $\begin{array}{l}\text { Load/ fuel } \\
\text { type }\end{array}$ & Diesel & $\begin{array}{l}\text { COME 5 / } \\
\text { JOME 5 }\end{array}$ & $\begin{array}{l}\text { COME 10 / } \\
\text { JOME 10 }\end{array}$ & $\begin{array}{l}\text { COME 15/ } \\
\text { JOME 15 }\end{array}$ & $\begin{array}{l}\text { COME 20 / } \\
\text { JOME 20 }\end{array}$ \\
\hline $25 \%$ & 0.55 & $0.54 / 0.522$ & $0.53 / 0.515$ & $0.54 / 0.508$ & $0.583 / 0.569$ \\
$50 \%$ & 0.69 & $0.678 / 0.609$ & $0.662 / 0.599$ & $0.694 / 0.58$ & $0.747 / 0.721$ \\
$75 \%$ & 0.81 & $0.788 / 0.836$ & $0.767 / 0.793$ & $0.911 / 0.775$ & $0.972 / 0.845$ \\
$100 \%$ & 0.97 & $0.911 / 1.009$ & $0.88 / 0.979$ & $1.04 / 0.951$ & $1.166 / 1.02$ \\
\hline
\end{tabular}

Table 6. ANOVA table for COME and JOME blends.

\begin{tabular}{|c|c|c|c|c|c|}
\hline $\begin{array}{l}\text { Source of } \\
\text { variation }\end{array}$ & $\begin{array}{l}\text { Sum of } \\
\text { squares } \\
\text { (COME / } \\
\text { JOME) }\end{array}$ & $\begin{array}{l}\text { Degrees } \\
\text { of } \\
\text { freedom }\end{array}$ & $\begin{array}{l}\text { Mean } \\
\text { square } \\
\text { (COME / } \\
\text { JOME) }\end{array}$ & Variation ratio or $\mathrm{F}$ & $\begin{array}{l}\text { F Table value } \\
\text { (COME / } \\
\text { JOME) }\end{array}$ \\
\hline $\begin{array}{l}\text { Between } \\
\text { fuel type }\end{array}$ & $\begin{array}{l}0.06272 / \\
0.0167\end{array}$ & 4 & $\begin{array}{l}0.01568 / \\
0.004175\end{array}$ & $\begin{array}{l}\mathrm{F}_{\mathrm{COME}}=0.01568 / 0.00654= \\
2.397 \mathrm{~F}_{\mathrm{JOME}}=0.004175 / \\
0.0025=1.67\end{array}$ & $3.26 / 3.26$ \\
\hline $\begin{array}{l}\text { Between } \\
\text { load \% }\end{array}$ & $0.5 / 0.59$ & 3 & $\begin{array}{l}0.166 / \\
0.197\end{array}$ & $\begin{array}{l}\mathrm{F}_{\mathrm{COME}}=0.166 / 0.00654= \\
25.38 \mathrm{~F}_{\mathrm{JOME}}=0.1973 / \\
0.0025=78.92\end{array}$ & 3.49 / 3.29 \\
\hline Residual & $\begin{array}{l}0.0785 / \\
0.03\end{array}$ & 12 & $\begin{array}{l}0.00654 / \\
0.0025\end{array}$ & & \\
\hline Total & $\begin{array}{l}0.641 / \\
0.636 \\
\end{array}$ & 19 & & & \\
\hline
\end{tabular}

\section{Statistical ANOVA Test (Thermal Efficiency with \% of Load)}

Two-way ANOVA tests were conducted on five fuel types for the observed data shown in Table 7. After application of ANOVA test, Table 8 was formed. For $v_{4,12}$, table value of $F_{0.05}=3.26$, which is less than the calculated value (5.75), the null hypothesis is rejected, hence there is a significant effect on thermal efficiency with the fuel type. For $v_{3,12}$, table value of $F_{0.05}=3.49$, which is less than the calculated value (120.38), the 
null hypothesis is rejected, hence there is a significant effect on thermal efficiency with the $\%$ of load. Similarly for JOME blends Table 7 shows the observed data. For $v_{4,12}$, table value of $F_{0.05}=3.26$, which is less than the calculated value (5.69), the null hypothesis is rejected, hence there is a significant effect on thermal efficiency with the fuel type. For $v_{3,12}$, table value of $F_{0.05}=3.49$, which is less than the calculated value (354.766), the null hypothesis is rejected, hence there is a significant effect on thermal efficiency with the \% of load.

Table 7. Observed data for COME and JOME blends.

\begin{tabular}{llllll}
\hline $\begin{array}{l}\text { Load/ fuel } \\
\text { type }\end{array}$ & Diesel & $\begin{array}{l}\text { COME 5 / } \\
\text { JOME 5 }\end{array}$ & $\begin{array}{l}\text { COME 10 / } \\
\text { JOME 10 }\end{array}$ & $\begin{array}{l}\text { COME 15 / } \\
\text { JOME 15 }\end{array}$ & $\begin{array}{l}\text { COME 20 / } \\
\text { JOME 20 }\end{array}$ \\
\hline $25 \%$ & 11.23 & $11.3 / 11.6$ & $11.45 / 11.8$ & $11.3 / 12.02$ & $10.4 / 10.75$ \\
$50 \%$ & 17.7 & $17.87 / 19.95$ & $18.32 / 20.35$ & $17.5 / 20.6$ & $16.29 / 16.97$ \\
$75 \%$ & 22.43 & $23.07 / 21.8$ & $23.78 / 23.6$ & $19.96 / 23.6$ & $18.73 / 21.76$ \\
$100 \%$ & 24.9 & $26.604 / 24.08$ & $27.4 / 25.66$ & $23.34 / 25.66$ & $20.8 / 23.95$ \\
\hline
\end{tabular}

Table 8. ANOVA table for COME and JOME blends.

\begin{tabular}{|c|c|c|c|c|c|}
\hline $\begin{array}{l}\text { Source of } \\
\text { variation }\end{array}$ & $\begin{array}{l}\text { Sum of squares } \\
\text { (COME / } \\
\text { JOME) }\end{array}$ & $\begin{array}{l}\text { Degrees of } \\
\text { freedom }\end{array}$ & $\begin{array}{l}\text { Mean } \\
\text { square }\end{array}$ & Variation ratio or $\mathrm{F}$ & $\begin{array}{l}\text { F Table } \\
\text { value }\end{array}$ \\
\hline $\begin{array}{l}\text { Between } \\
\text { fuel type }\end{array}$ & $32.44 / 10.75$ & 4 & $\begin{array}{l}8.11 / \\
2.689\end{array}$ & $\begin{array}{l}\mathrm{F}_{\mathrm{COME}}=8.11 / 1.41= \\
5.75 \mathrm{~F}_{\mathrm{JOME}}=2.689 / \\
0.4720=5.69\end{array}$ & $3.26 / 3.26$ \\
\hline $\begin{array}{l}\text { Between } \\
\text { load \% }\end{array}$ & $509.22 / 502.35$ & 3 & $\begin{array}{l}169.74 / \\
167.45\end{array}$ & $\begin{array}{l}\mathrm{F}_{\mathrm{COME}}=169.74 / 1.41 \\
=120.38 \mathrm{~F}_{\mathrm{JOME}}= \\
167.45 / 0.4720= \\
354.766\end{array}$ & $3.49 / 3.49$ \\
\hline Residual & $17.036 / 5.6651$ & 12 & $\begin{array}{l}1.41 / \\
0.472\end{array}$ & & \\
\hline Total & & 19 & & & \\
\hline
\end{tabular}

\section{Economics Related to Biodiesel Production}

Due to a substantial increase in the market price of diesel in recent years, the cost of biodiesel is coming closer to that of petroleum diesel. If this situation were to prevail for a somewhat longer duration, it may motivate oil producers to divert oil production to biodiesel production. In an attempt to study the possible role of various parameters, a formula has been devised, as shown in Eq. (2):

$$
E \leq \frac{[(A / B)-C]}{D}
$$

where $A$ is the unit price of petroleum diesel; $B$ is the ratio of calorific value of petroleum diesel to the calorific value of biodiesel or biodiesel equivalent of petroleum diesel. As the calorific value of biodiesel is less compared with the calorific value of petroleum diesel, the calorific value of biodiesel of jatropha oil $=37 \mathrm{MJ} / \mathrm{Kg}$ and calorific value of petroleum diesel $=42 \mathrm{MJ} / \mathrm{Kg}$, so the value of $\mathrm{B}=42 / 37=1.135 ; C$ is the processing cost per litre of biodiesel from oils; $D$ is the amount of oil required per 
litre of biodiesel (varies from 1.1 to 1.2); and $E$ is the maximum possible market price of oil to be used as feedstock for biodiesel production. Table 9 represents the variation of the maximum possible price of oil (as feedback for biodiesel production) with the price of petroleum diesel.

Table 9. Variation of the maximum possible price of oil.

\begin{tabular}{ccc}
\hline S. No & $\begin{array}{c}\text { Unit petroleum diesel } \\
\text { price A (Rs/Litre) }\end{array}$ & $\begin{array}{c}\text { Maximum allowable unit } \\
\text { price of oil E (Rs/Litre) }\end{array}$ \\
\hline 1 & 20 & 9.26 \\
2 & 30 & 16.60 \\
3 & 40 & 23.95 \\
4 & 50 & 31.29 \\
5 & 100 & 68 \\
\hline
\end{tabular}

Considering $\mathrm{B}=1.135, \mathrm{C}=6.5, \mathrm{D}=1.2$.

\section{CONCLUSIONS}

Jatropha oil methyl ester and castor oil methyl ester were prepared and mixed with diesel in four different proportions, i.e. 5\%, 10\%,15\%, and $20 \%$. With these blends short-term engine performance tests at varying loads were conducted. The engine parameters were recorded and compared. The best engine operating condition based on lower brake specific fuel consumption and higher brake thermal efficiency were identified. The maximum thermal efficiency was observed at $13 \%$ substitution of COME in diesel and $18 \%$ for JOME in diesel. Statistically the obtained parameters were checked with the help of the F test, which indicated that there is no significant effect on fuel consumption with the fuel type, there is a significant effect on fuel consumption with $\%$ of load, there is a significant effect on thermal efficiency with the fuel type, and there is a significant effect on thermal efficiency with the $\%$ of load. These trends indicated that blends in the ratio of $0-20 \%$ by volume of biodiesel can be added to neat diesel since the results are similar in nature to those obtained with neat diesel. A formula has been devised that takes into account the different factors which will motivate oil producers to divert oil production towards biodiesel production. Based on the formula, oil producers will have an idea of what point it will be beneficial to divert the oil production towards biodiesel production. Based on the obtained results it is recommended that:

i) $13 \%$ COME by volume has to be added to neat diesel to get better results with the engine.

ii) Following the same pattern,18\% JOME by volume has to be added to neat diesel as fuel to get better results.

iii) The formula $E \leq[(A / B)-C] / D$ can be used as a parameter by oil producers to evaluate whether to divert oil production towards biodiesel production.

\section{ACKNOWLEDGMENTS}

Authors would like to thanks Manav Rachna International University for providing laboratory facilities and funding for carrying out the engine tests in the Internal Combustion Engine Laboratory of the University. 


\section{REFERENCES}

[1] Agarwal AK, Das L. Biodiesel development and characterization for use as a fuel in compression ignition engines. Journal of Engineering for Gas Turbines and Power. 2000;123:440-7.

[2] Agarwal AK. Biofuels (alcohols and biodiesel) applications as fuels for internal combustion engines. Progress in Energy and Combustion Science. 2007;33:23371.

[3] Ma F, Hanna MA. Biodiesel production: a review. Bioresource Technology. 1999;70:1-15.

[4] Sahoo P, Das L, Babu M, Naik S. Biodiesel development from high acid value polanga seed oil and performance evaluation in a CI engine. Fuel. 2007;86:44854.

[5] Kamil M, Rahman MM, Bakar RA. Performance evaluation of external mixture formation strategy in hydrogen fueled engine. Journal of Mechanical Engineering and Sciences. 2011;1:87-98.

[6] Kamil M, Rahman MM, Bakar RA. Integrated simulation model for composition and properties of gases in hydrogen fueled engine. International Journal of Automotive and Mechanical Engineering. 2013;8:1242-155.

[7] Kamil M, Rahman MM, Bakar RA. An integrated model for predicting engine friction losses in internal combustion engines. International Journal of Automotive and Mechanical Engineering. 2014;9:1695-708.

[8] Usta N. Use of tobacco seed oil methyl ester in a turbocharged indirect injection diesel engine. Biomass and Bioenergy. 2005;28:77-86.

[9] Sudhir C, Sharma N, Mohanan P. Potential of waste cooking oils as biodiesel feedstock. Emirates Journal for Engineering Research. 2007;12:69-75.

[10] Yu C, Bari S, Ameen A. A comparison of combustion characteristics of waste cooking oil with diesel as fuel in a direct injection diesel engine. Proceedings of the Institution of Mechanical Engineers, Part D: Journal of Automobile Engineering. 2002;216:237-43.

[11] Kumar Tiwari A, Kumar A, Raheman H. Biodiesel production from jatropha oil (Jatropha curcas) with high free fatty acids: An optimized process. Biomass and Bioenergy. 2007;31:569-75.

[12] Pramanik K. Properties and use of Jatropha curcas oil and diesel fuel blends in compression ignition engine. Renewable Energy. 2003;28:239-48.

[13] Nayak C, Pattanaik BP, Nayak SK. Effect of preheated jatropha oil and jatropha oil methyl ester with producer gas on diesel engine performance. International Journal of Automotive and Mechanical Engineering. 2014;9:1709-22.

[14] Chakrabarti MH, Ali M. Performance of compression ignition engine with indigenous castor oil biodiesel in Pakistan. NED University Journal of Research. 2009;6:10-9.

[15] Naik M, Meher L, Naik S, Das L. Production of biodiesel from high free fatty acid Karanja (Pongamia pinnata) oil. Biomass and Bioenergy. 2008;32:354-7.

[16] Bari S, Yu C, Lim T. Performance deterioration and durability issues while running a diesel engine with crude palm oil. Proceedings of the Institution of Mechanical Engineers, Part D: Journal of Automobile Engineering. 2002;216:785-92. 
[17] Mat Yasin MH, Mamat R, Sharma KV, Yusop AF. Influence of palm methyl ester (PME) as an alternative fuel in multicylinder diesel engine. Journal of Mechanical Engineering and Sciences. 2012;3:331-9.

[18] Oliveira LS, Franca AS, Camargos RR, Ferraz VP. Coffee oil as a potential feedstock for biodiesel production. Bioresource Technology. 2008;99:3244-50.

[19] Ghadge SV, Raheman H. Biodiesel production from mahua (Madhuca indica) oil having high free fatty acids. Biomass and Bioenergy. 2005;28:601-5.

[20] Ramadhas AS, Jayaraj S, Muraleedharan C. Biodiesel production from high FFA rubber seed oil. Fuel. 2005;84:335-40.

[21] Chisti Y. Biodiesel from microalgae. Biotechnology Advances. 2007;25:294306.

[22] Sinha S, Agarwal AK, Garg S. Biodiesel development from rice bran oil: Transesterification process optimization and fuel characterization. Energy Conversion and Management. 2008;49:1248-57.

[23] Nelson RG, Schrock MD. Energetic and economic feasibility associated with the production, processing, and conversion of beef tallow to a substitute diesel fuel. Biomass and Bioenergy. 2006;30:584-91.

[24] Chiu C-W, Schumacher LG, Suppes GJ. Impact of cold flow improvers on soybean biodiesel blend. Biomass and Bioenergy. 2004;27:485-91.

[25] Ghai S, Das L, Babu MG. Emissions and performance study with sunflower methyl ester as diesel engine fuel. ARPN Journal of Engineering and Applied Sciences. 2008;3(5):75-80.

[26] Chhetri AB, Tango MS, Budge SM, Watts KC, Islam MR. Non-edible plant oils as new sources for biodiesel production. International Journal of Molecular Sciences. 2008;9:169-80. 